\title{
An unusual wooden foreign body in the face: a case report
}

Gilberto Leal Grade ${ }^{a}$, Roberta Dalmolin Bergoli de Almeida ${ }^{a}$, Leandro Calcagno Reinhardt ${ }^{a}$, Marcos Antonio Torriani ${ }^{\mathrm{a}}$

\begin{abstract}
Although injuries with the presence of foreign bodies in the maxillofacial region are relatively common in urgency and emergency services, they still pose a diagnostic challenge that is related to several factors, such as type of trauma, foreign body material, patient's level of consciousness and anatomical site involved. A third of foreign bodies in the face are not detected upon initial examination and may remain in deep tissues until they are accidentally encountered by imaging tests for other purposes or until the patient shows symptoms such as pain or swelling. This article reports a case of a $9 \mathrm{~cm}$ piece of wood extracted from a patient's middle third region of the left midface after 30 days of trauma occurrence, with associated infection suggesting a clinical picture of neoplasia.
\end{abstract}

Key words: Foreign Body; Infeccion; Maxillary

\section{Um corpo estranho de madeira incomum na face: relato de caso}

\section{RESUMO}

Apesar dos ferimentos com a presença de corpos estranhos na região maxilofacial serem relativamente comuns nos serviços de urgência e emergência, eles ainda representam um desafio diagnóstico devido a fatores como: tipo de trauma, tipo de material do corpo estranho, localização anatômica e nível de consciência do paciente. Um terço dos corpos estranhos presentes na face não são detectados no exame inicial e permanecem nos tecidos profundos até que sejam detectados, acidentalmente, através de exames de imagem realizados para outros fins, ou no momento em que o paciente apresenta sintomatologia como dor e/ou edema. O presente artigo relata o caso da remoção de um pedaço de madeira de $9 \mathrm{~cm}$ do terço médio da face esquerda do paciente, com infecção associada e imagem sugestiva de neoplasia, 30 dias após o acidente.

Palavras-chave: Corpo estranho; Infecção; Maxila

\author{
Department of Oral and Maxillofacial Surgery and \\ Trauma, School of Dentistry, Federal University of \\ Pelotas, Pelotas, Brazil
}




\section{INTRODUCTION}

The presence of foreign bodies in the maxillofacial area is relatively common when it comes to the occurrence of objects introduced in the nasal cavity. Puncture wounds on the face, caused by the introduction of an object such as a knife, piece of iron, wood, firearm projectile or different kinds of debris that break the skin or mucous barriers and enter the body are rare, with few reports in literature [1,2].

The diagnosis of the presence of foreign bodies in the face is challenging, and depends on a number of particularities involved, such as type of trauma, foreign body material, the patient $>$ s state of consciousness, his ability to report the incident, as well as the anatomical site involved. Approximately one-third of foreign bodies inoculated in the maxillofacial region are detected in the first visit [2].

Glass, plastic and wooden objects cannot be viewed in conventional radiographs. Depending on their deeper or shallower location, or on anatomical sites where viewing is difficult or not palpable upon physical examination, and depending on the patientss level of consciousness, there may be inaccuracies in the collection of trauma history, hampering the clinical examination and consequent diagnosis. Although some foreign bodies can be left "untouched" for clinical reasons, most of them should be removed due to eventual complications, especially infections. The treatment is surgical and should be planned according to anatomy, entry hole and object size $[2,3]$.

This paper presents a case of trauma by a penetrating foreign body in the maxillofacial region, with a wooden fragment lodged in the soft tissue and associated infection, mimicking a clinical picture leading to neoplasia suspicion. The patient was informed on treatment specificities and accepted the conditions as well as eventual use of the case for publication, according to the standard free informed consent of the Dentistry School of the Federal University of Pelotas.

\section{CASE REPORT}

A 35 year old male patient sought the Pelotas County Emergency complaining of an edema on his left midface showing a 2 week evolution (Figure 1). In the interview, the patient could not think of any recent traumas or injuries except for the extraction of element 25, 7 days earlier. Upon clinical examination, asymmetry of the face with a swelling on the left midface was observed. Intraoral examination revealed the presence of a submucosal nodule of fibrous consistency approximately $2 \mathrm{~cm}$ by $3 \mathrm{~cm}$ in size in the left cheek mucosa area near the parotid duct. There were local phlogistic signs, mild pain on palpation, and intact mucosa without lacerations or purulent drainage. A Watters radiographic examination, PA and profile radiographs of the face were requested, but no alterations were evidenced.

(Figure 2A-B-C).

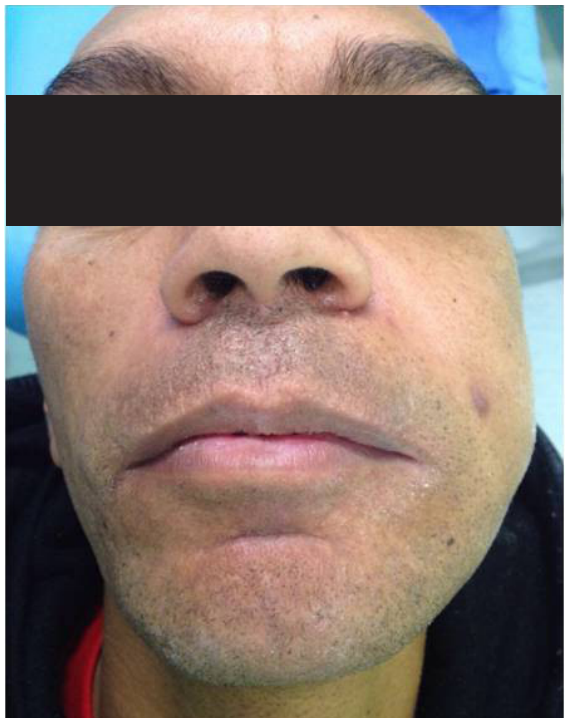

Figure 1. Diffuse edema in the left midface
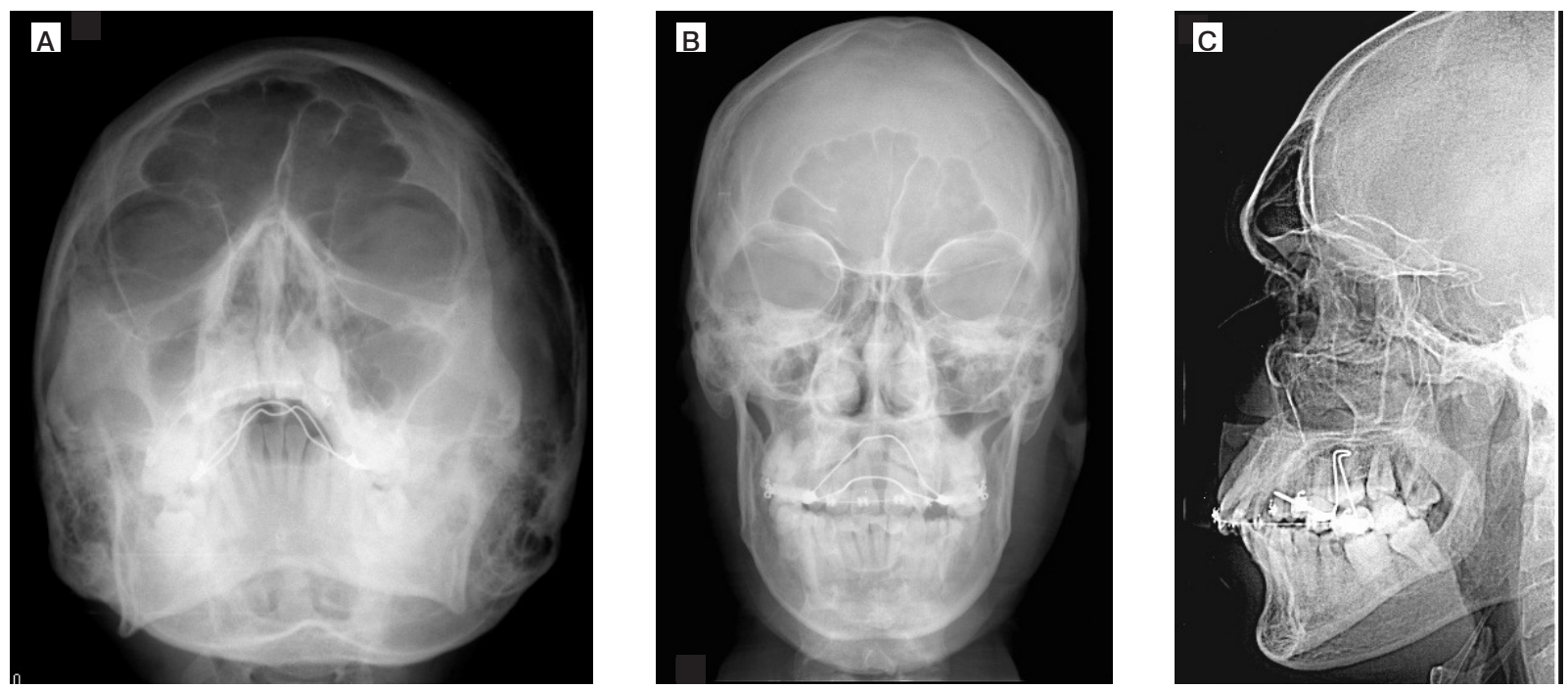

Figure 2. (A) Water's view; (B) Posteroanterior Radiograph; (C) Lateral Radiograph 


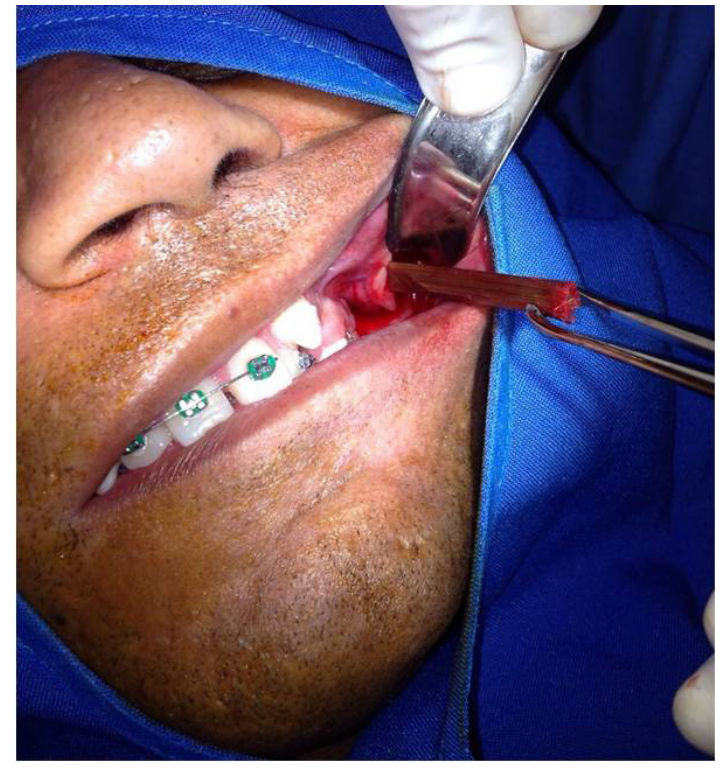

Figure 3. Clamping and removal of foreign body

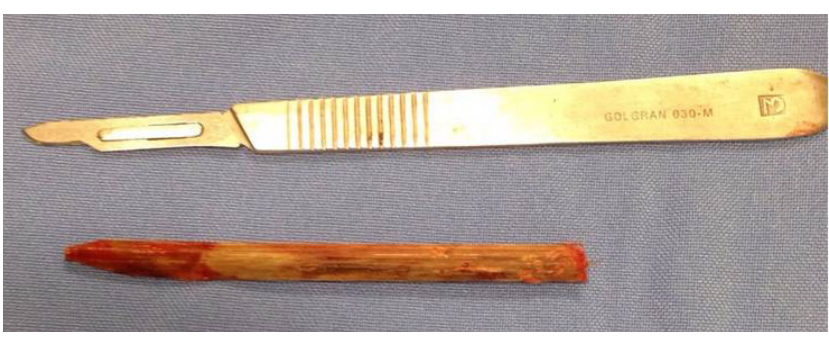

Figure 4. Removed foreign body

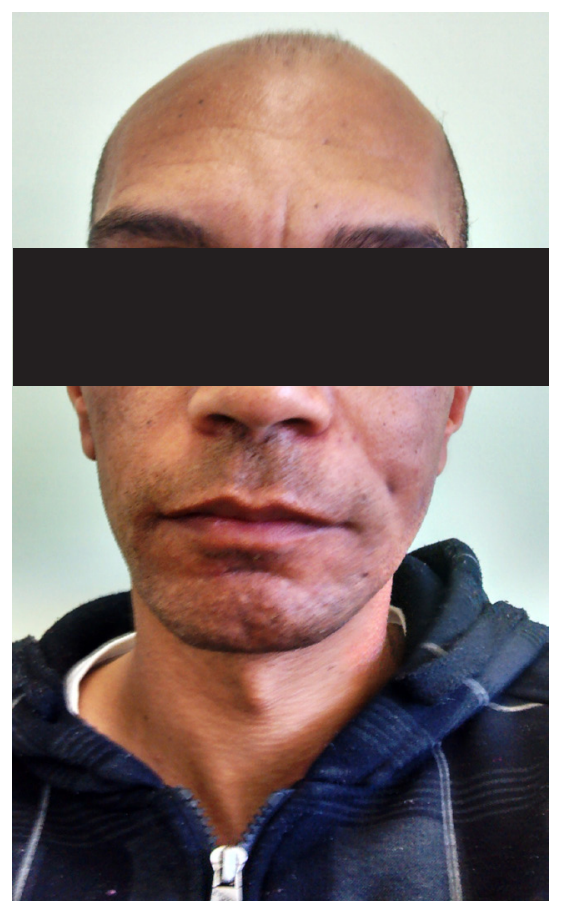

Figure 5. Clinical photograph of the patient one week postoperatively
At first, a purulent fluid was punctured and an oral antiinflammatory drug and follow-up were prescribed. After three days, the patient returned to the Emergency, reporting fever and pain. An antibiotic drug (500 mg amoxicillin) was then prescribed and an assessment at the Diagnostic Center of Mouth Diseases (DCMD) of the Federal University of Pelotas was scheduled. Upon consultation, fine-needle aspiration (FNA) of the lesion area was recommended, inasmuch as, due to the proximity to the parotid gland and rapid evolution, a salivar gland tumor lesion was suspected. Microscopic analysis did not elucidate the case, revealing only inflammatory cells.

Pre-operative tests were requested and an incisional biopsy was scheduled, which was carried out in an outpatient setting under local anesthesia. One semilunar incision above the parotid duct and tissue dissection were made until the likely injury could be reached. At that moment there was extravasation of a sero-bloody secretion, with volume decrease. Further digital palpation revealed a hardened mass of bony tissue consistency with slight mobility. This mass was pinched, and its mobility and absence of tensile strength were evidenced. Following, the mass was removed with gentle traction movements, and a foreign body (barbecue wooden stick) of about $9 \mathrm{~cm}$ long was revealed.

Upon being informed what it was, the patient recalled that 1 month earlier he had been assaulted while eating barbecue, having lost his senses, and thus could not remember what had happened. The case was therefore elucidated. Sequential treatment included the prescription of anti-inflammatory and analgesic drugs, with full remission post-operative behavior. (Figure 5)

\section{DISCUSSION}

The presence of foreign bodies in the maxillofacial area might entail risks for the patient, especially in cases where blood vessels of large caliber are involved and the resulting bleeding might lead to progressively severe situations; also, the close contact of these bodies with important structures such as nerves and salivary glands may result in a number of problems [4-9]. The list of objects described in literature includes sharp wooden sticks, screwdrivers, nails, iron bars, spears, knives, ice picks, umbrella handles, harpoons, fishing hooks, keys, drills, needles, forks, metal fragments, toys and pencils. These foreign bodies may be inactive and stay in tissues for a long time without causing damage to adjacent structures [3, 10-12]. However, foreign bodies usually carry dirt and microorganisms, so there may be concomitant infections $[2,3,13]$. Penetrating foreign bodies always present a diagnostic challenge for the professionals involved, especially in decision-making in the case of an intervention, as this is an unpredictable surgery which is not part of the daily routine and because there are no location, shape, texture on palpation and radiographic analysis patterns. Surgical access must take into account characteristics previously described by associating these with the anatomy of the region and the object entry 
path $[8,14,15]$. As for location, inasmuch as the oral mucosa area near the parotid duct has a high incidence of salivary gland benign tumors, especially pleomorfic adenomas [7,9], foreign bodies inserted in this region are often difficult to diagnose, especially if a consistent history of trauma cannot be obtained. CT and MRI scans are the most appropriate exams so as to outline the history and position of organic foreign bodies, as well as the presence of intracranial bone fragments, bleeding and to assess central nervous system damage. A thorough medical history is also important in order to obtain as much relevant information as possible for a full diagnosis $[3,14,15]$. In the case here presented, the patient only reported having ingested alcohol in excess and an ensuing physical aggression later, and only sought treatment two weeks after the incident, which contributed to a difficult and confusing diagnosis. Since signs of infection and inflammation associated with a prior extraction site followed, the first diagnosis hypothesis was odontogenic infection. This was dropped due to the lack of a septic focus and no remission with drainage and antibiotics therapy. Imaging exams available were not elucidatory. Through the information available a tumor lesion was suspected, and the clinical management followed this bias.

\section{CONCLUSION}

The presence of foreign bodies in the craniofacial region is usual, consisting mostly of inorganic material. In the case of wooden foreign bodies, the casuistry decreases and the difficulty of diagnosis and correct treatment increases. The foreign body should be removed as soon as possible, since the porous characteristic of most of these materials favors bacterial colonization. Information provided by radiographic examination is either low or non-existent; because of this, it is advisable to do other imaging tests such as ultrasound and magnetic resonance imaging when the presence of a metal object has been ruled out. The procedure in case of wooden foreign bodies is surgical, aiming at the complete removal of the object, and should take into account: the clinical history, the exact location and characteristics of the object, as well as the length of time it remained in the tissues in question.

\section{REFERENCES}

1. Regineli A, Santagata M, Urraro F, Somma F, Izzo A, Cappabianca S Rotondo A: Foreign Bodies in the Maxillofacial Region: Assessment With Multidetector Computed Tomography. Semin Ultrasound CT MRI. 2014; 36:2-7. https://doi.org/10.1053/j.sult.2014.10.009

2. Loganathan K, Chacko JP, Saravanan BS, Vaithilingam B: Management of wooden foreign bodies in craniofacial region. Journal of Oral Biology and Craniofacial Research.2012;2:210-212. https://doi.org/10.1016/j. jobcr.2012.10.011

3. Peterson JJ, Bancroft LW, Kransdorf MJ: Wooden foreign bodies: Imaging appearance. AJR Am J Roentgenol. 2002; 78:557-62. https:// doi.org/10.2214/ajr.178.3.1780557

4. Sodhi KS, Coleman L: Impacted intranasal foreign body causing orbital cellulitis and mistaken for orbital pathology. Afr J Paediatr Surg. 2010; 27:215-6. https://doi.org/10.4103/0189-6725.70435

5. Takasaki K, Enatsu K, So E, Takahashi H: Fifty-four wooden toothpicks in the nasal cavity. Otolaryngol Head Neck Surg. 2005;132:669-70. https:// doi.org/10.1016/j.otohns.2004.09.073

6. Ebner Y, Golani D, Ophir D, Finkelstein Y: Penetrating injury of the maxilla by needlefish jaws. J Cranio Maxillofac Surg. 2009; 37: 235-8. https://doi. org/10.1016/j.jcms.2008.12.001

7. Verma P, Sachdeva SK, Verma KG, Sachdeva K: Pleomorphic adenoma of cheek: a rare case report and review of literature. Indian J Dent Res. 2014;25:122-4. https://doi.org/10.4103/0970-9290.131166

8. Vikram A, Mowar A, Kumar S: Wooden Foreign Body Embedded in the Zygomatic Region for 2 Years. J Maxillofac Oral Surg. 2012;11:96-100. https://doi.org/10.1007/s12663-010-0161-1

9. Dalati T, Hussein MR: Juvenile pleomorphic adenoma of the cheek: a case report and review of literature. Diagn Pathol. 2009;4:32. https://doi. org/10.1186/1746-1596-4-32

10. Moham S, Varghese G, Kumar S, Subramanian DP: Penetrating facial injury by a wooden log. National Journal of Maxillofacial Surgery. 2014; 5:228-31. https://doi.org/10.4103/0975-5950.154844

11. Mohiuddin SA, Rahiman S, Sultana S: Multiple glass pieces in paranasal sinuses. Indian J Dent Res. 2011;22:847-9. https://doi.org/10.4103/09709290.94683

12. Ho VT, McGuckin JF, Jr, Smergel EM: Intraorbital wooden foreign body: CT and MR appearance. AJNR Am J Neuroradiol. 1996;17:134-6.

13. Rudagi BM, Halli R, Kini Y, Kharkhar V, Saluja H: Foreingbodies in facial trauma - report of 3 cases. J Maxillofac oral surg. 2013;12:210. https:// doi.org/10.1007/s12663-010-0072-1

14. Tandon NP, Gupta DS, Jurel SK, Srivastava S, Sharma S: Penetranting injury of face by a large machine bolt - a rare case report. J Maxillofac oral Surg. 2015; 14:100-102. https://doi.org/10.1007/s12663-0120343-0

15. Webb BD, Pereira KD, Fakhri S: Nasal foreign body as the cause of a subperiosteal orbital abscess in a child. Ear Nose Throat J. 2010; 89:E11-3. 